\title{
PRODUKSI BIOGAS DARI LIMBAH RUMAH TANGGA SEBAGAI UPAYA MENGATASI KRISIS ENERGI DAN PENCEMARAN LINGKUNGAN
}

\author{
Marsudi \\ Dosen Teknik Mesin Universitas Muhammadiyah Metro \\ Jl. Ki Hajar Dewantara No. 116 Kampus 15 A Kota Metro Lampung \\ marsudi@yahoo.com
}

\begin{abstract}
Abstrak: Limbah rumah tangga merupakan komponen yang cukup berbahaya jika dibuang begitu saja karena akan menimbulkan bau busuk, penyakit dan mencemari air terutama air tanah yang banyak dipakai sebagai air minum. Untuk itu perlu diolah sebagai energi alternative biogas. Penelitian ini bertujuan untuk mengetahui bagaimana produksi dan karaktristik proses fermentasi limbah, berapa banyak biogas yang dapat dihasilkan, berapa lama waktu permentasi. Metode penelitiannya yaitu pembuatan alat reaktor dan pengujian dengan memasukkan limbah rumah tangga yang dicampur kotoran ternak dan air ke dalam reaktor lalu mencatat hasilnya kemudian menguji biogasnya. Reaktor biogas dengan volume 120 liter terdiri dari tampungan utama limbah dan tampungan biogas. saluran masuk dan saluran keluar limbah, juga saluran keluar biogas. Proses fermentasi berlangsung pada kondisi tanpa oksigen. Prinsip Kerja Reaktor Biogas yaitu limbah cair tahu dimasukkan ke dalam reaktor yang kedap udara, memanfaatkan proses pencernaan yang dilakukan oleh bakteri methanogen yang produknya berupa gas methana $(\mathrm{CH} 4)$. Proses fermentasi berlangsung selama 50 hari dengan hasil-hasil sebagai berikut dari 100 liter limbah rumah tangga, kotoran ternak dan air yang diproses fermentasi maka didapat biogas sejumlah 0,55432 $\mathrm{m}^{3}$ atau 554,32 liter biogas. Dengan tekanan tertinggi $106,5 \mathrm{kN} / \mathrm{m}^{2}$. Temperatur yang terjadi di dalam reaktor $29-31^{\circ} \mathrm{C}$ sesuai dengan batas aman yang diisaratkan untuk permentasi yaitu $25^{\circ} \mathrm{C}-40^{\circ} \mathrm{C}$
\end{abstract}

Kata kunci : Limbah, Biogas, Energi

\section{Pendahuluan}

Masalah pencemaran lingkungan terutama di kota-kota, telah menunjukkan gejala yang cukup serius, terutama masalah pencemaran air, yang disebabkan oleh salah satunya ialah limbah rumah tangga. Air buangan limbah rumah tangga yang jumlahnya makin hari makin besar sesuai dengan semakin besarnya laju pertumbuhan penduduk dan perkembangan kota-kota besar, maka terjadi penurunan kualitas lingkungan. Padatnya pemukiman dan kondisi sanitasi lingkungan yang buruk serta rendahnya kesadaran sebagian masyarakat yang langsung membuang kotoran atau sampah ke dalam badan sungai, tanpa proses pengolahan telah menyebabkan pencemaran lingkungan. Air limbah dari buangan rumah tangga ratarata perorang per hari adalah 118 liter, dengan konsentrasi BOD rata-rata 236 $\mathrm{mg} / \mathrm{liter}$. Dari studi tersebut juga diketahui bahwa air limbah rumah tangga memberikan kontribusi terhadap pencemaran air sekitar 75 $\%$, air limbah perkantoran dan daerah komersil $15 \%$, dan air limbah industri sekitar $10 \%$. Sedangkan dilihat dari polutan organiknya, air limbah rumah tangga sekitar $70 \%$, air limbah perkantoran $14 \%$, dan air limbah industri $16 \%$. Dengan demikian air limbah rumah tangga penyumbang terbesar tarhadap pencemaran air. 
Beberapa langkah yang dapat diambil untuk mengatasi pencemaran tersebut diantaranya yaitu dengan pemanfaatan limbah rumah tangganya tersebut sebagai bahan baku untuk energi laternatif biogas dimana proses produksinya dilakukan melalui proses fermentasi anaerobik didalam suatu ruang pencerna (digester) yang hampa udara.

Biogas memiliki peluang yang besar dalam pengembangannya. Energi biogas dapat diperoleh dari air limbah rumah tangga, kotoran hewan ternak, sampah organik dari pasar, sampah daun kering, industri makanan dan sebagainya. Bahan input produksi biogas menjadi tersentralisir dan ketersediannya terjamin secara kontinyu karena mudah didapat. Selain potensi yang besar, pemanfaatan energi biogas dengan digester biogas memiliki banyak keuntungan, yaitu mengurangi efek gas rumah kaca, mengurangi bau yang tidak sedap, mencegah penyebaran penyakit, menghasilkan panas dan daya (mekanis/listrik). Pemanfaatan limbah dengan cara seperti ini secara ekonomi akan sangat kompetitif seiring naiknya harga bahan bakar minyak.

Proses pembuatan biogas dengan menggunakan biodigester pada prinsipnya adalah menciptakan suatu sistem kedap udara dengan bagian-bagian pokok yang terdiri dari tangki pencerna (digester tank), lubang input bahan baku, lubang output lumpur sisa hasil pencernaan (slurry) dan lubang penyaluran biogas yang terbentuk. Dalam digester terkandung bakteri metana yang akan mengolah limbah organik menjadi biogas.

Penelitian ini bertujuan untuk mengetahui banyaknya biogas yang dihasilkan dari limbah rumah tangga yang digunakan serta karaktristik proses fermentasi yang terjadi pada proses inraturmpei, seperti volume, tekanan serta temperatur.

\section{Kajian Pustaka}

Air limbah adalah kotoran dari masyarakat dan rumah tangga dan juga yang berasal dari industri, air tanah, air permukaan serta buangan lainnya, dengan demikian air buangan ini merupakan hal yang bersifat kotoran umum.

Air limbah sangat berbahaya terhadap kesehatan manusia mengingat bahwa banyak penyakit yang dapat ditularkan melalui air limbah. Air limbah ini ada yang hanya berfungsi sebagai media pembawa saja seperti penyakit kolera, radang usus, hepatitis infektiosa, serta schitosomiasis. Selain sebagai pembawa penyakit di dalam air limbah itu sendiri banyak terdapat bakteri patogen penyebab penyakit, dan mengandung bahan-bahan beracun, penyebab iritasi, bau dan bahkan suhu yang tinggi serta bahan-bahan lainnya yang mudah terbakar.

Limbah rumah tangga merupakan pencemar air terbesar selain limbah limbah industri, pertanian dan bahan pencemar lainnya. Limbah rumah tangga akan mencemari selokan, sumur, sungai, dan lingkungan sekitarnya. Semakin besar populasi manusia, semakin tinggi tingkat pencemarannya. Limbah rumah tangga adalah limbah yang berasal dari dapur, kamar mandi, cucian, limbah bekas industri rumah tangga dan kotoran manusia. Limbah rumah tangga dapat berupa padatan (kertas, plastik dll.) maupun cairan (air cucian, minyak goreng bekas, dll.). Di antara limbah tersebut ada yang mudah terurai yaitu sampah organik dan ada pula yang tidak dapat terurai. Limbah rumah tangga ada juga yang memiliki daya racun tinggi, misalnya sisa obat, baterai bekas, air aki. Limbah-limbah tersebut tergolong bahan berbahaya dan beracun (B3). Tinja, air cucian, limbah kamar mandi dapat mengandung bibit-bibit penyakit atau pencemar biologis (seperti bakteri, jamur, virus, dan sebagainya) yang akan mengikuti aliran air.

Air merupakan kebutuhan pokok kehidupan manusia di bumi ini. Sesuai dengan kegunaanya, air dipakai sebagai air minum, mandi, mencuci, untuk pengairan pertanian, sanitasi, transportasi, baik di sungai maupun di laut. Kegunaan air tersebut termasuk sebagai kegunaan air secara konvensional.

Pencemaran air merupakan salah satu pecemaran berat yang ada di Indonesia, dan limbah rumah tangga adalah sumber penyebab pencemaran yang paling dominan. Pencemaran air ini di timbulkan dari sektorsektor industri maupun rumah tangga. Dan akibat dari pencemaran air tersebut adalah menurunnya kadar kualitas air yang dapat dimanfaatkan oleh manusia.

Biogas merupakan gas campuran metana (CH4), karbondioksida (CO2) dan gas lainnya yang didapat dari hasil penguraian bahan organik (seperti kotoran hewan, kotoran manusia, dan tumbuhan) oleh 
bakteri metanogen. Untuk menghasilkan biogas, bahan organik yang dibutuhkan, ditampung dalam biodigester. Proses penguraian bahan organik terjadi secara anaerob (tanpa oksigen). Biogas terbentuk pada hari ke 4-5 sesudah biodigester terisi penuh dan mencapai puncak pada hari ke 2025. Biogas yang dihasilkan sebagian besar terdiri dari $50-70 \%$ metana ( $\mathrm{CH} 4), 30-40 \%$ karbondioksida (CO2) dan gas lainnya dalam jumlah kecil (BPPT., 1997a).

Biogas mempunyai nilai kalor yang cukup tinggi sekitar 4800 sampai 6700 $\mathrm{kkal} / \mathrm{m}^{3}$, sebanyak $1000 \mathrm{ft}^{3}\left(28,32 \mathrm{~m}^{3}\right)$ biogas sama dengan galon ( 1 US gallon $=3,785$ liter) butane atau 5,2 gallon gasolin (bensin) atau 4,6 gallon minyak diesel. Untuk memasak pada rumah tangga dengan 4-5 anggota keluarga cukup $150 \mathrm{ft}^{3}$ per hari (Goendi S,2008). Komponen terbesar biogas adalah Methana $\left(\mathrm{CH}_{4}, 54-80 \%\right.$ volume $)$ dan karbodioksida $\left(\mathrm{CO}_{2}, 20-45 \%\right.$ volume) serta sejumlah kecil $\mathrm{H}_{2}, \mathrm{~N}_{2}$ dan $\mathrm{H}_{2} \mathrm{~S}$. (Siska, RSN, 2010).

Biogas dihasilkan apabila bahanbahan organik terurai menjadi senyawasenyawa pembentuknya dalam keadaan tanpa oksigen (anaerob). Fermentasi anaerobik ini biasa terjadi secara alami di tanah yang basah, seperti dasar danau dan di dalam tanah pada kedalaman tertentu. Proses fermentasi adalah penguraian bahan-bahan organik dengan bantuan mikroorganisme. Fermentasi anaerob dapat menghasilkan gas yang mengandung sedikitnya 50\% metana. Gas inilah yang biasa disebut dengan biogas. Biogas dapat dihasilkan dari fermentasi sampah organik seperti sampah pasar, daun daunan, dan kotoran hewan yang berasal dari sapi, babi, kambing, kuda, atau yang lainnya, bahkan kotoran manusia sekalipun. Gas yang dihasilkan memiliki komposisi yang berbeda tergantung dari jenis hewan yang menghasilkannya.

Biogas dapat dijadikan sebagai bahan bakar karena mengandung gas metana $(\mathrm{CH} 4)$ dalam prosentase yang cukup tinggi. Komponen biogas selengkapnya adalah sebagai berikut:

Tabel 2.1 Komposisi Biogas Secara Umum.

\begin{tabular}{|l|c|}
\hline \multicolumn{1}{|c|}{ Jenis Gas } & Jumlah (\%) \\
\hline Metana (CH4) & $50-70$ \\
Nitrogen (N2) & $0-0,3$ \\
Karbondioksida (CO2) & $25-45$ \\
Hidrogen (H2) & $1-5$ \\
Oksirugen (O2) & $0,1-0,5$ \\
Hidrogen Sulfida (H2S) & $0-3$ \\
\hline
\end{tabular}

Sumber : BPPT.,1997a.

Reaktor biogas adalah merupakan suatu alat yang berbentuk kubah yang berfungsi menampung limbah rumah tangga dan sebagai tempat berlangsungnya proses fermentasi yaitu proses pembentukan gas metah (CH4). Reaktor ini memiliki beberapa bagian. Bagian pertama adalah digester sebagai tempat pencerna material biogas dan sebagai rumah bagi bakteri, baik bakteri pembentuk asam maupun bakteri pembentuk gas. Kemudian saluran, di mana terdapat dua bagian saluran yaitu saluran masuk dari limbah yang mau difermentasi dan saluran keluar limbah yang sudah difermentasi. Selanjutnya bagian saluran keluar gas metan, yaitu gas yang sudah difermentasi disalurkan ke panampungan biogas. Dan terakhir saluran

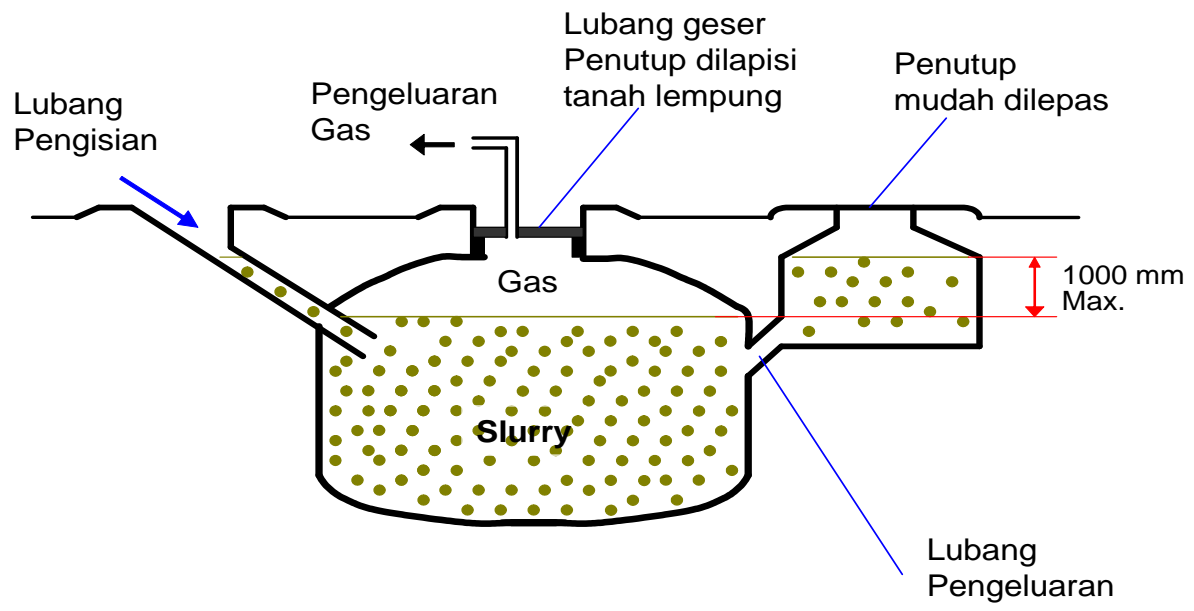

Gambar 2.1. Reaktor kubah tetap (Fixed Dome) 
buang yaitu udara dan gas yang tercampur di awal fermentasi dibuang terlebih dahulu untuk menjaga kemurnian gas metan yang dihasilkan.

Secara garis besar proses pembentukan biogas dibagi menjadi tiga tahapan, yaitu:

a. Tahap Hidrolisis (Hydrolysis)

Pada tahap ini, bakteri memutuskan rantai panjang karbohidrat kompleks; protein dan lipida menjadi senyawa rantai pendek. Contohnya polisakarida diubah menjadi monosakarida, sedangkan protein diubah menjadi peptide dan asam amino.

b. Tahap Asidifikasi (Acidogenesis dan Acetogenesis)

Pada tahap ini, bakteri (Acetobacter aceti) menghasilkan asam untuk mengubah senyawa rantai pendek hasil proses hidrolisis menjadi asam asetat, hidrogen, dan karbon dioksida. Bakteri tersebut merupakan bakteri anaerob yang dapat tumbuh dan berkembang dalam keadaan asam. Bakteri memerlukan oksigen dan karbondioksida yang diperoleh dari oksigen yang terlarut untuk menghasilkan asam asetat. Pembentukan asam pada kondisi anaerobik tersebut penting untuk pembentukan gas metana oleh mikroorganisme pada proses selanjutnya. Selain itu bakteri tersebut juga mengubah senyawa berantai pendek menjadi alkohol, asam organik, asam amino, karbon dioksida, hidrogen sulfida, dan sedikit gas metana.Tahap ini termasuk reaksi eksotermis yang menghasilkan energi.

c. Tahap Pembentukan Gas Metana (Methanogenesis)

Pada tahap ini, bakteri Methanobacterium omelianski mengubah senyawa hasil proses asidifikasi menjadi metana dan $\mathrm{CO} 2$ dalam kondisi anaerob. Proses pembentukan gas metana ini termasuk reaksi eksotermis.

Secara umum terbentuknya biogas adalah melalui proses degradasi limbah baik dari limbah pertanian, kotoran hewan, dan kotoran manusia atau campurannya yang dicampur dengan air dan ditempatkan dalam tempat yang tertutup atau dalam kondisi anaerob/kedap udara (Hadi dkk., 1982). Keadaan anaerob ini dapat terjadi secara buatan yaitu dengan membuat digester sebagai tempat terjadinya proses degradasi limbah organik (Gede S.N.L.2007). Kondisi anaerob dalam bak pencerna inilah yang kemudian berkembang dengan bermacamacam bentuk dan bahan yang digunakan. Gas bio (methan) sebagai produk utama dari instalasi biogas merupakan campuran dari berbagai jenis gas.

\section{Metode Penelitian}

Metoda penelitian yang digunakan yaitu kegiatan rancang bangun pembuatan alat Reaktor (digester), Perancangan dan pembuatan reaktor skala Lab. yaitu untuk menentukan fungsi, ukuran, bentuk dan tata letak dari komponen utama serta banyaknya limbah cair tahu yang dapat ditampung pada proses anaerobic. Kapasitas reaktor yaitu 120 liter.

Menentukan perbandingan jumlah limbah rumah tangga dengan air dan kotoran sapi. Yaitu limbah rumah tangga 80 liter, air 14 liter dan kotoran sapi $6 \mathrm{~kg}$ Volume, semua dicampur menjadi satu dan dimasukkan ke dalam reaktor dan kemudian ditutup.

Pengujian alat yaitu melakukan proses fermentasi terhadap limbah rumah tangga. Dengan memasukkan limbah kedalam drum reactor kemudian di tutup untuk mendapatkan proses anaerob yaitu proses fermentasi dengan tanpa udara luar. Beberapa data yang perlu dicatat seperti tekanan, volume dan temperatur serta jumlah hari yang terjadi selama proses fermentasi belangsung.

Pengukuran yang dilakukan pada reaktor yaitu Temperatur biogas di dalam dan di luar sekitar reaktor (digester). Tekanan biogas di dalam reaktor serta valume biogas. Pengukuran dilakukan setiap hari hingga hari terakhir dimana volem dan tekanan biogas yang dihasilkan tidak banyak lagi.

Proses pengujian yang dilakukan yaitu :

a. Masukan air, limbah rumah tangga dan kotoran sapi ke dalam reaktor melalui sisi masuk

b. Sisakan ruang kosong di dalam reaktor $20 \%$ sebagai tempat fermentasi gas metannya

c. Catat beberapa data seperti tekanan, temperatur setiap harinya. Dan Setelah \pm 1 minggu, biasanya gas pertama mulai terbentuk di dalam reaktor, ditandai dengan naiknya tekanan pada manometer-U.

d. Karena gas tersebut bercampur dengan udara yang ada pada awal 
pengujian, maka biogas ini harus dibuang melalui kran pembuangan, karena tidak bagus.

e. Untuk hari berikutnya pengumpulan gas sudah bisa dimasukkan ke dalam tampungan.

f. Catat beberapa data-data ukuran dari sampel yang sudah ada, seperti temperatur, tekanan dan volume gas yang dihasilkan. Amati hingga hari

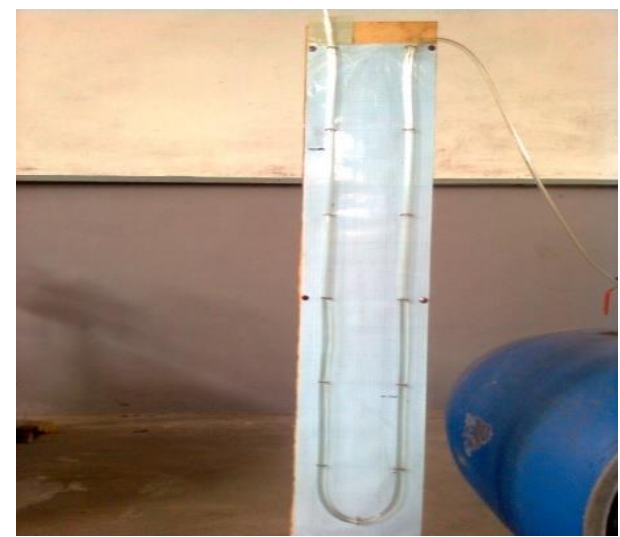

Gambar 3.2. Manometer - U dimana hasil gas metan sudah tidak ada lagi.

g. Biogas yang dihasilkan yang terkumpul dipenampungan tersebut lalu di uji dengan menggunakan kompor gas.

h. Catat semua hasil yang didapat lalu diolah dan dianalisa kemudian disimpulkan.

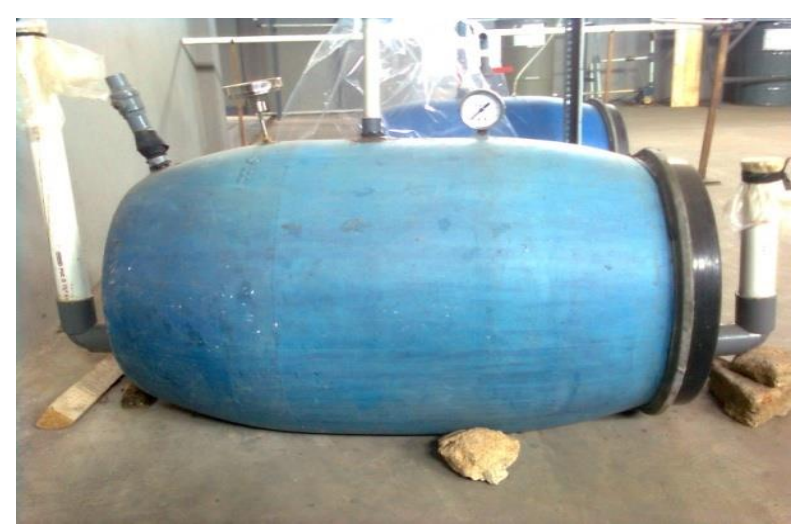

Gambar 3.1. Reaktor Biogas

\section{Hasil dan Pembahasan}

Dari hasil pengujian alat reaktor dan pengukuran data yang telah dilakukan di dapat hasilnya bahwa pengaruh mulai timbulnya pada hari ke lima dan menghasilkan biogas, volume dan tekanan gas serta temperatur yang dihasilkan dapat lihat pada Tabel dan Grafik di bawah ini.

Table 4.1. Data hasil pengukuran Temperatur, Tekanan dan volume biogas

\begin{tabular}{|c|c|c|c|c|}
\hline No. & $\begin{array}{c}\text { Waktu } \\
(\text { hari })\end{array}$ & $\begin{array}{c}\text { Temperatur } \\
\left({ }^{0} \mathbf{C}\right)\end{array}$ & $\begin{array}{c}\text { Tekanan } \\
\left({ }_{\mathrm{k}} \mathbf{N} / \mathbf{m}^{\mathbf{2}}\right)\end{array}$ & $\begin{array}{c}\text { Volume } \\
(\text { liter })\end{array}$ \\
\hline 1. & 5 & 29 & 101.65 & 4.81 \\
\hline 2. & 10 & 30 & 102.55 & 19.42 \\
\hline 3. & 15 & 30 & 103.30 & 34.10 \\
\hline 4. & 20 & 29 & 104.75 & 59.72 \\
\hline 5. & 25 & 29 & 105.95 & 85.65 \\
\hline 6. & 30 & 29 & 106.50 & 98.39 \\
\hline 7. & 35 & 29 & 105.70 & 82.50 \\
\hline 8. & 40 & 30 & 105.15 & 75.32 \\
\hline 9. & 45 & 31 & 104.60 & 64.91 \\
\hline 10. & 50 & 30 & 102.65 & 29.50 \\
\hline & Total & \multicolumn{3}{|l}{} \\
\hline
\end{tabular}




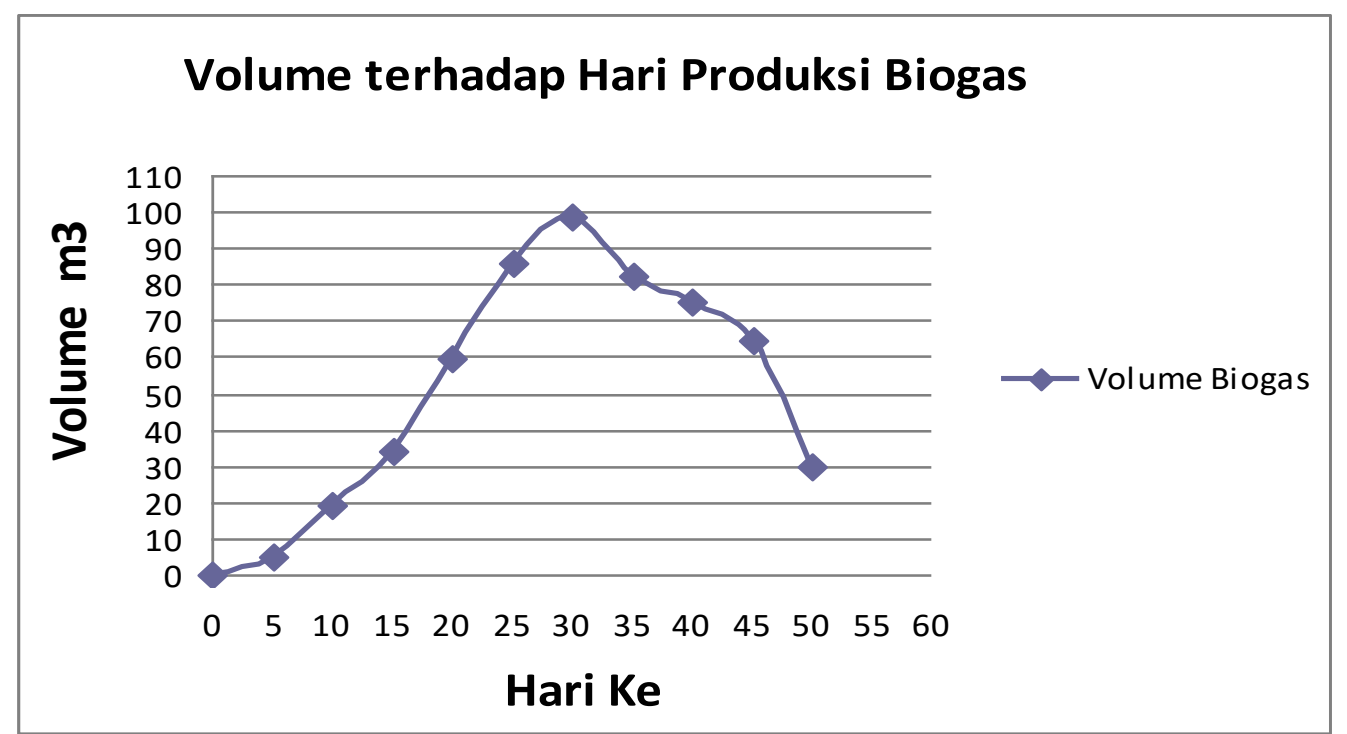

Gambar 4.1. Grafik hubungan Volume terhadap Hari produksi biogas

\section{Tekanan terhadap Hari Produksi Biogas}

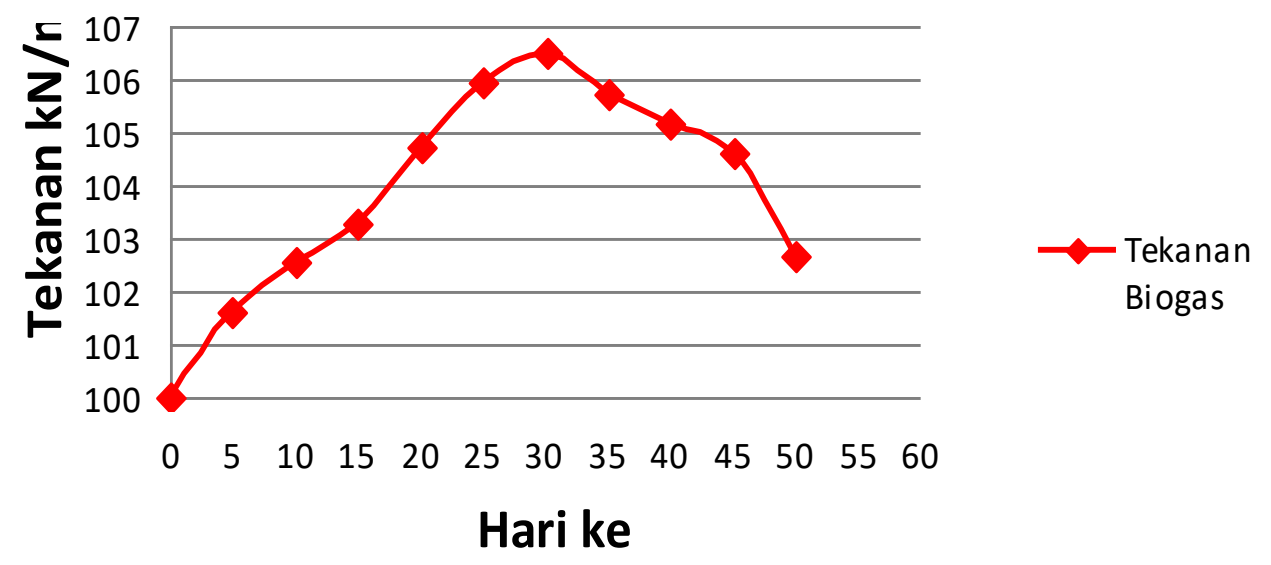

Gambar 4.2. Grafik hubungan Tekanan terhadap Hari produksi biogas 


\section{Temperatur terhadap Hari Produksi Biogas}

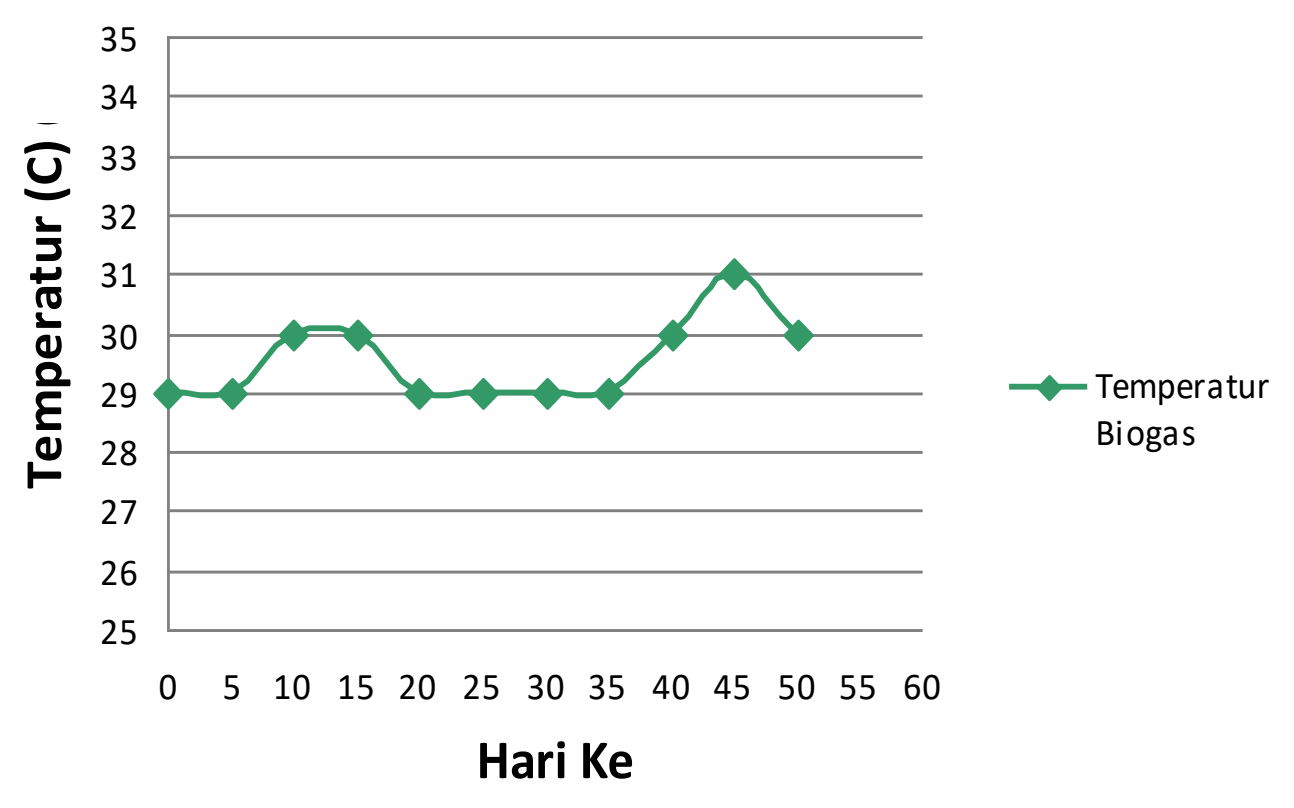

Gambar 4.3. Grafik hubungan Temperatur terhadap Hari produksi biogas

Dari tabel 4.1. dan gambar 4.1. dapat lihat bahwa mulai pertumbuhan volume biogas terlihat mulai hari ke empat (4) yang terakumulasi pada hari ke lima (5) yaitu sebesar 4,81 liter. Kemudian pertumbuhan volume biogas terus maningkat menunjukkan peningkatan yang berarti seiring bertambahnya hari. Namun pada hari ke tiga puluh (30) di sini terlihat merupakan pertumbuhan volume biogas yang tertinggi yaitu sebesar 98,39 liter. Selanjutnya pertumbuhan volume biogas terus menurun namun nilainya masih cukup besar dan pada hari ke lima puluh (50) terlihat bahwa jumlah volume biogas sudah sangat kecil sekali yaitu 29,50 liter sehingga diperkirankan pertumbuhan biogas sudah tidak ada lagi. Dengan demikian jumlah volume biogas yang dihasilkan keseluruhan selama proses fermentasi tersebut yaitu 554,32 liter dengan limbah rumah tangga yang digunakan 100 liter.

Pada tabel 4.1. dan gambar 4.2. terlihat pertumbuhan tekanan biogas yang terjadi hampir sama seperti volume biogas yaitu mulai tumbuh tekanan pada hari ke empat (4) yaitu sebesar 101,65 kN/m2. Dan pertumbuhan tekanan terus bertambah seiring berjalannya hari dan puncak pertumbuhan terjadi pada hari ke tiga puluh (30) yaitu sebesar 106,50 kN/m2. Selanjutnya pertumbuhan tekanan terus turun hingga pada hari ke lima puluh (50) besar tekanaan yang terjadi sudah kecil sekali yaitu $102,65 \mathrm{kN} / \mathrm{m}^{2}$.

Kemudian tabel 4.1. dan gambar 4.3. batwa temperatur yang terjadi pada proses fermentasi tidak terlalu jauh berbeda dari masing-masing hari yaitu berkisar $29^{\circ} \mathrm{C}$ sampai $31^{\circ} \mathrm{C}$, hal ini dapat dinyatakan bahwa proses fermentasi berlangsung pada kondisi temperatur yang baik untuk pertumbuhan biogas yaitu berkisar $25^{\circ} \mathrm{C}$ sampai $40^{\circ} \mathrm{C}$ (Geondi, S., 2008). Seperti terlihat pada tabel 4.1. dan gambar grafik 4.3.

Pertumbuhan biogas masih terus terjadi lebih dari hari ke lima puluh (50) namun pertumbuhannya sangat kecil sekali maka diambil waktu produktif pada fermentasi ini hanya pada hari ke lima puluh (50).

\section{Pemenuhan kehutuhan bahan bakar}

Dengan pengolahan (fermentasi) limbah rumah tangga sebanyak 100 liter menghasilkan biogas sebanyak 554,32 liter atau A,55432 m'. Dengan nilai kalori bahan 
bakar biogas sekitar $4785 \mathrm{kkal} / \mathrm{m}^{3}$ atau 4,785 kkal/liter (Pertiwiningrum A, 2009) berarti akan menghasilkan kalori sebanyak 2.652 kilokalori. Dengan demikian bahwa limbah rumah tangga sangat produktuf sebagai bahan bakar jika diolah dengan serius apalagi disaat harga bahan bakar fosil sekarang sangat mahal. Disamping itu pengolahan limbah rumah tangga juga dapat mengatasi pencemaran lingkungan terutama bagi sumber air tanah.

\section{Pembahasan}

Produksi dan karaktristik proses pengolahan limbah rumah tangga menjadi biogas cukup mudah dan murah. Yaitu dengan menyiapkan sebuah reaktor yang tidak begltu besar kemudian masukkan limbah rumah tangga dengan ditambah sedikit kotoran sapi lalu diamkan beberapa hari dan tunggu proses fermentasi untuk menjadi gas. Sediakan tampungan gas dan gas dengan sendirinya akan terkumpul. Dan gas siap digunakan dengan menghubungkan ke sebuah kompor gas. Proses fermentasi memang cukup lama namun selama proses fermentasi tidak diperlukan perlakuan khusus sehingga dirasa tidak merepotkan. Cukup masukkan limbah ke dalam reaktoro lalu futup kemudian tunggu hasilnya.

Dengan menggunakan reaktor berkapasitas 120 liter dengan rincian 100 liter limbah rumah tangga air + kotoran sapi. Dan ruang hampa udara sekitar 20 liter. Setelatr difermentasi dan menghasilkan biogas sebanyak 554,32 liter atau $0,55432 \mathrm{~m}^{3}$. Jika di nilai dengan kalori dimiliki oleh biogas sekitar $4785 \mathrm{kka} / \mathrm{m}^{3}$ atau $4,785 \mathrm{kka} /$ liter akan menghasilkan kalori sebanyak 2.652 kilokalori. Untuk mendapatkan hasil biogas yang optimumo maka perlu dilakukan beberapa perlakuan, seperti mengaduk-aduk limbah secara berkala untuk selalu menghidupkan (mengaktifkan) mikrobamikroba penghasil gas metan.

Berdasarkan permentasi timbah rumah tangga yang terah di lakukan pada reaktor biogas maka diketahui waktu optimal yang diperlukan kurang lebih lima puluh hari (50). volume biogas mulai terbentuk pada hari ke empat puncak pertumbuhan biogas maksimum pada hari ke 30 dan pertumbuhan biogas yang tidak produktif lagi yaitu pada hari ke liftfa puluh. Jumlatr biogas masih dapat dihasilkan pada hari terakhir tersebut namun sudah tidak banyak lagi (sedikit) sehingga dapat dihentikan.

\section{Kesimpulan}

Dari hasil penelitian yang telah dilakukan dan didapatkan hasil maka dapat disimpulkan sebagai berikut :

1. Produksi dan karaktristik proses fermentasi cukup simpel dan sederhana tidak memerlukan perlakuan khusus, cukup masukan dan funggu hasilnya.

2. Dari 100 liter limbah rumah tangga air + kotoran sapi setelah difemrentasi dan menghasilkan biogas sebanyak 554,32 liter sama dengan $0,55432 \mathrm{~m}^{3}$ atau sebanyak 2.652 kilokalori.

3. Waktu fermentasi yang optimum adalah 50 hari, dengan mulai timbul biogas pada hari ke 4 dan hari ke 30 merupakan pertumbuhan biogas yang maksimum.

\section{DAFTAR PUSTAKA}

Bappeda Medan, 1994, Penelitian Pencemaran Air Limbah Di Sentra Industri kecil Tahu/ Tempe di Kec. Medan Tuntungan Kotamadya Dati II Medan, Laporan Penelitian, Bappeda TK II Medan, Medan.

BPPT, 1997a, Teknologi Pengolahan Limbah Tahu-Tempe Dengan Proses biofilter Anaerob dan Aerob, http://www.enviro.bppt.go.id (tgl. 24 september 2008)

Damayanti, Alia,. Dkk, 2004, Analisis Resiko Lingkungan Dari Pengolahan Limbah Pabrik Tahu Dengan Kayu Apu, Jurnal Purifikasi, Vol.5, No.4, Oktober 2004, Institut Teknologi Surabaya, Surabaya.

Gede Sudaryanti N L, dkk, 2007, Pemanfaatan Sedimen Perairan Tercemar Sebagai Bahan Lumpur Aktif Dalam Pengolahan Limbah Cair Industri Tahu, Laporan Penelitian, Universitas Udayana Bali

Goendi, Sunanto., dkk, 2008, Kajian Model Digester Limbah Cair Tahu Untuk Produksi Biogas Berdasrkan Waktu Penguraian, Prosiding Seminar Nasianal Teknik 
Pertanian 2008, Universitas Gajah Mada, Yogyakarta

Pertiwiningrum, Ambar., 2009, Pengolahan Limbah Organik Menjadi Biogas Dengan Menggunakan Alat Gama Bioporta, Laporan Penelitian, Universitas Gajah Mada, Yogyakarta.

Siska, R. S. N,. 2010, Pengaruh Waktu Tinggal Dan Komposisi Bahan
Baku Pada Proses Fermentasi Limbah Cair Industri Tahu Terhadap Produksi Biogas, Tesis, Universitas Sumatera Utara, Medan

Syamsuddin, T.R, dkk. 2005, Bahan Bakar Alternatif Asal Ternak, Sinar Tani, Edisi 21-27 Desember 2005, No 3129 Tahun XXXVL. 